\title{
Pharmacy Technician Workload and Workforce Requirements at MOH Hospitals during Ten years Mass Gathering Hajj (2006-2015) in Makah Region, Saudi Arabia
}

\author{
Yousef Ahmed Alomi*1, Khairat Alhennawi ${ }^{2}$, Nizar Khayayt ${ }^{3}$ \\ ${ }^{1}$ The Past General Manager of General Administration of Pharmaceutical Care and \\ Head, National Clinical pharmacy, and pharmacy practice and Pharmacy $R \& D$ Administration, \\ Ministry of Health, Riyadh, KSA. \\ ${ }^{2}$ Clinical pharmacy staff, General Administration of Pharmaceutical Care, Ministry of Health, Riyadh, KSA. \\ ${ }^{3}$ Medication Safety Officer General Administration of Pharmaceutical care, Makkah Region, \\ Ministry of Health, Riyadh, KSA.
}

Received: 13 August 2017;
Accepted: 28 September 2017
*Correspondence to:
Dr. Yousef Ahmed Alomi,

The Past General Manager of General Administration of Pharmaceutical Care Head, National Clinical pharmacy, and pharmacy practice Head, Pharmacy $R \&$ D Administration Ministry of Health, P.O.BOX 100, Riyadh 11392, Riyadh, Saudi Arabia. Email:yalomi@gmail.com

Copyright: (C) the author(s),publisher and licensee Indian Academy of Pharmacists. This is an openaccess article distributed under the terms of the Creative Commons Attribution Non-Commercial License, which permits unrestricted non-commercial use, distribution, and reproduction in any medium, provided the original work is properly cited.

Publishing Partner : EManuscript [www.emanuscript.in]

\begin{abstract}
Purpose: To explore the Pharmacy technician services workload analysis and human resources requirements at Ministry of Health Hospitals during mass gathering Hajj ten years (2007-2016), Saudi Arabia. Methods: It is a retrospective of ten years (2007-2015) of hospital Pharmacy technician workload during mass gathering Hajj period. The duration of workload collection was 15 days. The Pharmacy technician prepares the medications and pharmaceutical to all patients either Pilgrim or not Pilgrim at Makah region. It included Mona holy places hospitals; Arafa holy places hospitals, and Makah city. The workforce requirements calculated based on $\mathrm{MOH}$ workforce standards per bed and the workload drives as central Pharmacy technician services, patient specific Pharmacy technician activities, and Pharmacy technician administration specific pharmacy activities. Results: The total number of Pilgrims $(1,952,817-3,161,573)$ with average of $(2,445,208)$. The total number of prescriptions $(99,886-257,545)$ with average $(180,120)$, it represented $(5.11-12.07 \%)$ with average $(7.86 \%)$ of all pilgrims. The average number of pharmacy technician calculated per hospital was (17.74 FTE), while the mean number pharmacy technician needed based on workload for all services was (110.95FTE) per hospital in all Makka region. It is (6.12 fold) more incremental than $\mathrm{MOH}$ pharmacy technician workforce standards per bed. Conclusion: Despite the clinical pharmacy technician's activities missed with emphasis on patient-specific clinical pharmacy technician and administrative pharmacy technician performances. There is a high demand for pharmacy technician workforce during mass gathering Hajj period in Makah Region, Saudi Arabia.
\end{abstract}

Keyword: Pharmacy technician, Workload, Workforces, Mass Gathering, Hajj, Makka, Ministry of Health, Saudi Arabia

\section{INTRODUCTION}

Every year there is a huge mass gathering event occurred in holy cities in the kingdom of Saudi Arabia. The famous holy cities are Makka and Al-Madina. The mass gathering is defined as the presence of more than 1000 people together at the same period. ${ }^{[1]}$ The mass gathering event called Hajj. It is the fifth pillar of Islam. 
All Ministries in the Kingdom of Saudi Arabia provides the best services to Pilgrim including Ministry of Health. There was $\mathrm{MOH}$ strategic plan with multiple expansions of health care services over the years with best and high quality of medical services. ${ }^{[2-3]}$ The essential part of the services were human health care resources including physician pharmacist and nurses to work in all medical institutions. One of the core parts was pharmacy technician works at hospital and primary care centers. The last statistical report of Ministry of Health $(\mathrm{MOH})$ mentioned that some pharmacy technician worked at $\mathrm{MOH}$ organization was more than eight thousand while the pharmacist was three thousand and five hundred. ${ }^{[2]}$ That is almost more than thrice of a pharmacy technician is than a pharmacist. With a high workforce of pharmacy technician what's was the role of pharmacy technician at $\mathrm{MOH}$ institution in Saudi Arabia. The seldom to find a published literature discussed pharmacy technician in Saudi Arabia and any related issues. Also, there are insufficient studies on GCC countries or Middle East countries. However, there are several publications from the USA, Canada and Australia clarified that. ${ }^{[4-6]}$ Those countries try to improve the pharmacy technician performance to advance activities with clinical support to the clinical pharmacist. ${ }^{[7-8]}$ The pharmacy technician support and help the pharmacist at their pharmacy practice and clinical pharmacist performance. The General Administration of Pharmaceutical Care (GAPC) setup the standards of pharmacy technician requirements for hospitals and primary care centers at regular normal days ${ }^{[9]}$ However, there are no standards of pharmacy technician requirements during mass gathering events with an emphasis on Hajj time. The author is not familiar with any study in Saudi Arabia Middle East or even over the entire world about pharmacy technician workforce during mass gathering events including the Hajj. In this study, the authors explored the pharmacy technician workload and human resources during hajj in ten years period (2006-2015).

\section{METHODS}

It is a retrospective study of ten years (2006-2015) of pharmacy technician workload at hospitals during mass gathering Hajj period. The duration of workload collection was 15 days. The pharmacy technician prepares the medications and pharmaceuticals before dispensing to all patients either Pilgrim or not Pilgrim at Makah region. It included Mina holy places hospitals; Arafat holy places hospitals, and Makah city. All the data derived from Ministry of Health. Health Statistical Year Books. ${ }^{[10-19]}$ Also, there was extensive literature review search at open date periods with fifty databases included.
It included the type of studies (meta-analysis, randomized controlled studies, and observational studies, books, reports etc) in the English language. The search for the term of Hajj and workforce, Hajj and workforce, Hajj and human resources or mass gathering and workforce, mass gathering and workforce, mass gathering and human resources. The search term was in the title and key words. All setting of patient care services hospitals; inpatient or ambulatory care or community services included. The search included pharmacy technician workload. The location of studies included Saudi Arabia as top propriety if not existed Gulf or Middle East countries included, if not found overall counties included. The fifteen hospitals included in the study located in Makka city and Holy places. They all have Intensive Care Unit department, Emergency Room department, Surgery unit, Internal Medicine unit. ${ }^{[20-27]}$ The workforce requirements calculated based on $\mathrm{MOH}$ workforce standards per bed and the workload preparation of dispensing prescriptions. Moreover, from as central pharmacy technician services, patient specific pharmacy technician activities, and general administration specific pharmacy technician activities based on American college of clinical pharmacy society and other literature. ${ }^{[4,5,27-30]}$ The updated hospital's demographic information and the workload calculation based on pharmacy administration database in Makka region with considered that is an average time of pharmacy technician preparation for dispensing inpatient order was 3 minutes; while Ambulatory care and emergency 2 minutes. All calculation done used Microsoft Excel version ten.

\section{RESULTS}

There were fifteen hospitals in Makka city and holy places. The majority of them provided emergency and internal medicine services $15(100 \%)$ followed by surgery services $13(86.6 \%)$ and adults intensive care units $11(73.3 \%)$. Some hospitals got accreditations from local organization CBAHI $6(40 \%)$ while only a few hospitals had accreditation from international institution Joint commission 2 (13\%). Most of the hospital outpatient pharmacy, inpatient pharmacy and emergency with pharmacy store followed by extemporaneous preparation unit, medication safety officer and pharmacy total quality management 15(100\%) while missed clinical pharmacy services and medication reconciliation $0(0 \%)$ as explored in table 1 . The most pharmacy technician activities were Prepare the medications for dispensing Inpatient, OPD, Emergency Pharmacy, Distribution of floor stock medication, and Assistant for Extemporaneous preparation. Followed by assisting the pharmacist in the Pharmacy Total Quality and Pharmacy 


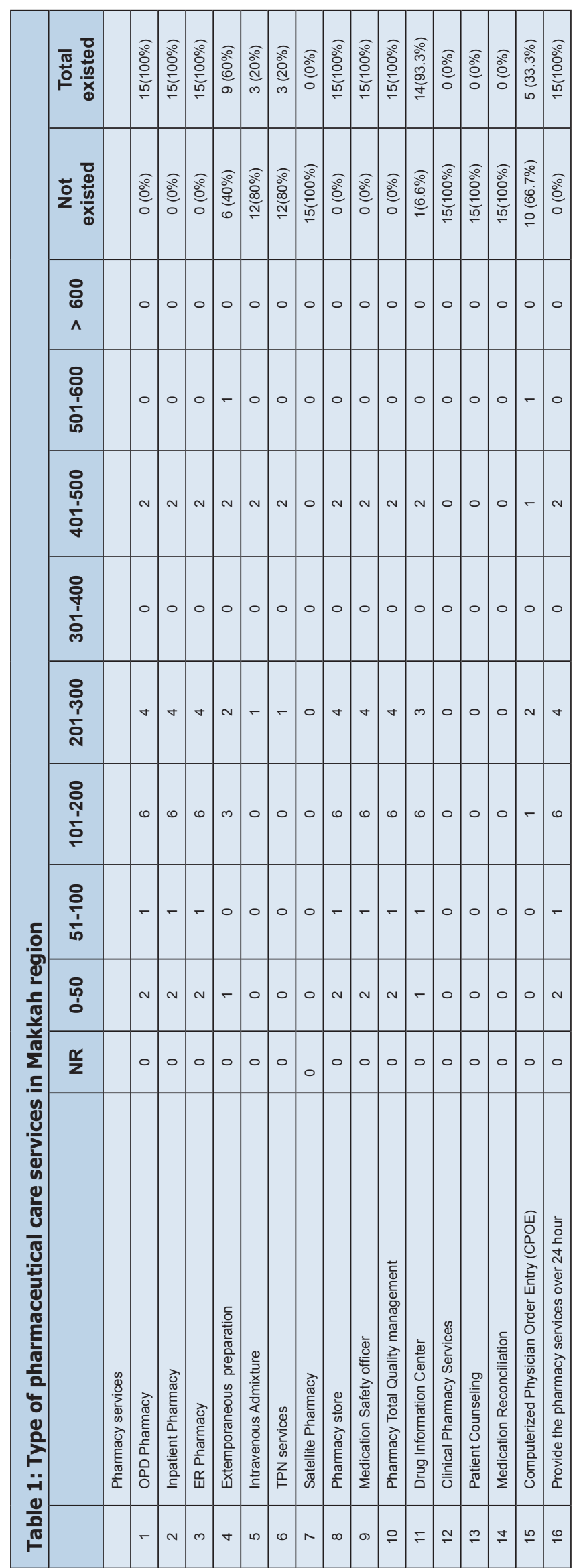

store and Documentation of Medication Safety officer reports $15(100 \%)$. While missed Documentation of Clinical Pharmacy Services Documentation of Patient Counseling and Assistant the pharmacist in the Medication Reconciliation $0(0 \%)$ as explored in table 2. The total number of Pilgrims over the ten years was $(1,952,817$ $3,161,573)$ with an average of $(2,445,208)$. The total number of the bed was $(2,350-3,609)$ with a mean $(2,868.60)$. The total number of prescriptions $(99,886-287,138)$ with average $(190,822)$, this percentage represented $(5.111$ $12.08 \%$ ) with average $(7.86 \%)$ of all pilgrims. From these prescriptions, an average of $(101,328.80)$ prescriptions in Makah, which represented (4.14\%) of all pilgrims, and an average of $(89,493.40)$ prescriptions were in holy places, which represented $(3.72 \%)$ of all pilgrims. The average number of Ambulatory care prescriptions was $(69,517)$ while $(22,959)$ was the average of emergency prescription, and $(2,935)$ for inpatient prescriptions. The average number of Ambulatory prescriptions per day $(4,517)$ contained $(13,551)$ medications, the emergency orders were $(1,492)$ per day contained $(4,476)$ drugs, and Inpatient prescriptions were (185) per day included (555) medications as explored in table 3-4. In Makka city, the inpatient services, the average number of pharmacy technician needed was 2.93 FTE (full-time employee) per hospital, while for Emergency service 16.18 FTE per hospital, and 35.46 FTE per hospital for Ambulatory care with the total average 54.56 FTE per hospital. In the holy places, the inpatient services, the average number of pharmacy technician needed was 1.82 FTE (full-time employee) per hospital, while for Emergency service 8.21 FTE per hospital, and 41.25 FTE per hospital for Ambulatory care with the total average 51.28 FTE per hospital as explored in table 3-4. The average number of pharmacy technician calculated per hospital was (17.74 FTE), while the mean number pharmacy technician needed based on workload for all services was (110.95 FTE) per hospital in all Makka region. It is (6.12 fold) more incremental than $\mathrm{MOH}$ pharmacy technician workforce standards per bed with the new suggestion of workforces as the number of pharmacy technician per bed during mass gathering Hajj period was 0.28 as explored in table 5 . There were not any central pharmacy technician activities, clinical pharmacy technician services or administrative pharmacy technician activities.

\section{DISCUSSION}

The general administration of Pharmaceutical Care released the pharmacy strategic plan in 2013 for all pharmacist and pharmacy technician. ${ }^{[31]}$ The pharmacy strategic plan based on $\mathrm{MOH}$ strategic plan for medical services. ${ }^{[3]}$ The consisted 
Pharmacy technician workforces at Hospitals during Hajj in Makka

\begin{tabular}{|c|c|c|c|c|c|c|c|c|c|c|c|c|c|c|c|c|c|c|c|c|c|c|c|c|}
\hline \multicolumn{2}{|c|}{ 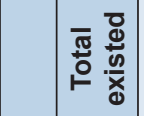 } & & 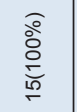 & 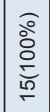 & 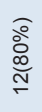 & 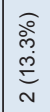 & 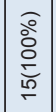 & 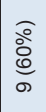 & 递 & $\mid \begin{array}{l}0 \\
\stackrel{0}{0} \\
0\end{array}$ & 今. & 总 & $\mid \begin{array}{l}\text { 高 } \\
\text { con }\end{array}$ & 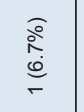 & 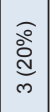 & $\mid \begin{array}{l}0 \\
\stackrel{0}{0} \\
0\end{array}$ & 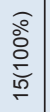 & 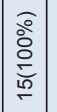 & 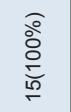 & $\begin{array}{l}\text { ò } \\
\text { Oे }\end{array}$ & 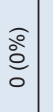 & ๖े & ङั & $\begin{array}{l}\text { òे } \\
\text { id } \\
\text { id }\end{array}$ \\
\hline & 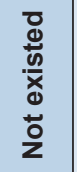 & & $\frac{\text { ò }}{\circ}$ & $\mid \begin{array}{l}0 \\
\text { oे } \\
0\end{array}$ & 递 & 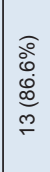 & 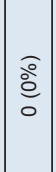 & 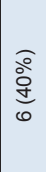 & 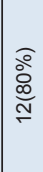 & 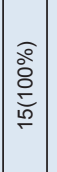 & 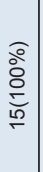 & 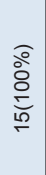 & 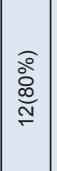 & 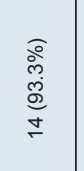 & 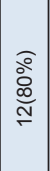 & 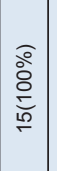 & $\mid \begin{array}{l}0 \\
\stackrel{0}{0} \\
0\end{array}$ & $\mid \begin{array}{l}0 \\
\stackrel{0}{0} \\
0\end{array}$ & ठัo & 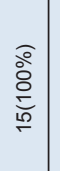 & 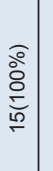 & 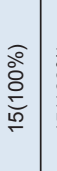 & 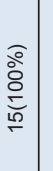 & $\begin{array}{l}\text { ले } \\
\text { ले } \\
\stackrel{c}{c}\end{array}$ \\
\hline & $\begin{array}{l}8 \\
\text { ¿ } \\
\wedge\end{array}$ & & 0 & 0 & $\circ$ & 0 & 0 & 0 & 0 & 0 & 0 & 0 & 0 & $\circ$ & 0 & 0 & 0 & 0 & 0 & 0 & $\circ$ & $\circ$ & $\circ$ & 0 \\
\hline & $\begin{array}{l}8 \\
0 \\
\vdots \\
1\end{array}$ & & 0 & 0 & $r$ & - & 0 & - & 0 & 0 & 0 & 0 & 0 & 0 & 0 & 0 & 0 & 0 & 0 & 0 & $\circ$ & 0 & 0 & 0 \\
\hline & 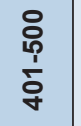 & & N & $\sim$ & 0 & 0 & $\sim$ & $\sim$ & $\sim$ & 0 & 0 & 0 & $\sim$ & - & $\sim$ & 0 & $\sim$ & $\sim$ & $\sim$ & 0 & $\circ$ & 0 & $\circ$ & - \\
\hline & ষ্ণ & & 0 & 0 & $\sim$ & - & 0 & 0 & 0 & 0 & 0 & 0 & 0 & 0 & 0 & 0 & 0 & 0 & 0 & 0 & $\circ$ & 0 & 0 & 0 \\
\hline 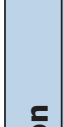 & 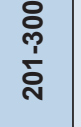 & & $\nabla$ & $\nabla$ & 0 & 0 & $\sigma$ & $N$ & - & 0 & 0 & 0 & - & 0 & - & 0 & $\nabla$ & $\sigma$ & $\nabla$ & $\circ$ & 。 & $\circ$ & $\circ$ & $\sim$ \\
\hline 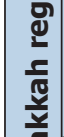 & ণัণ & & 0 & 0 & 0 & 0 & 0 & $m$ & 0 & 0 & 0 & 0 & 0 & 0 & 0 & 0 & 0 & 0 & 0 & 0 & 0 & 0 & 0 & $r$ \\
\hline $\begin{array}{l}2 \\
.5 \\
y \\
0\end{array}$ & $\frac{8}{\frac{1}{10}}$ & & - & - & 0 & 0 & - & 0 & 0 & 0 & 0 & $\circ$ & 0 & 0 & $\circ$ & $\circ$ & - & - & - & $\circ$ & 0 & $\circ$ & 0 & 0 \\
\hline है & ํㅗㅇ & & $N$ & $\sim$ & 0 & 0 & $\sim$ & - & 0 & 0 & 0 & 0 & 0 & 0 & 0 & 0 & $\sim$ & $\sim$ & $\sim$ & 0 & 0 & $\circ$ & 0 & 0 \\
\hline $\begin{array}{l}n \\
n \\
c \\
c\end{array}$ & $\frac{\underline{r}}{z}$ & & 0 & 0 & 0 & 0 & 0 & 0 & 0 & 0 & 0 & 0 & 0 & 0 & 0 & 0 & 0 & 0 & 0 & 0 & 0 & 0 & 0 & 0 \\
\hline 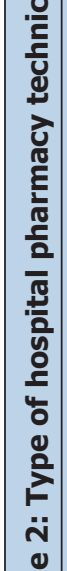 & & 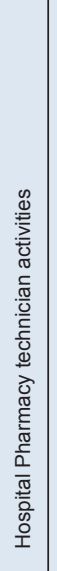 & 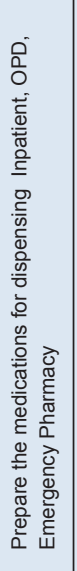 & 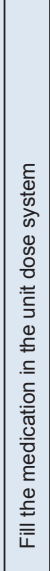 & 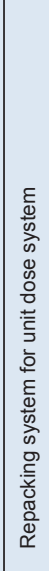 & 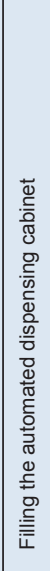 & 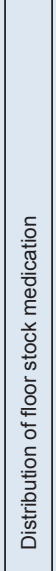 & 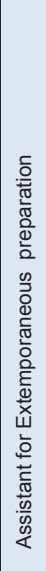 & 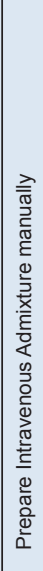 & 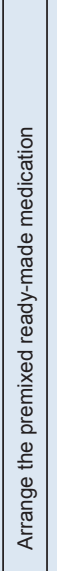 & 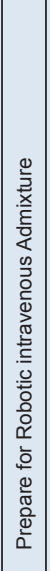 & 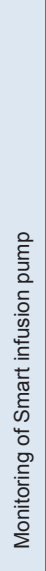 & 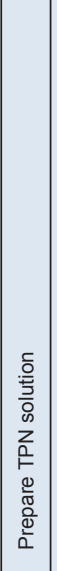 & 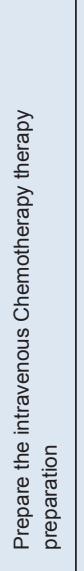 & 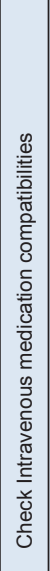 & 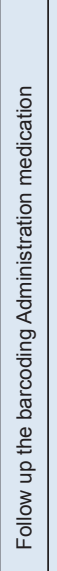 & 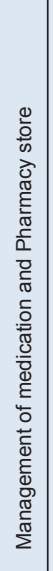 & 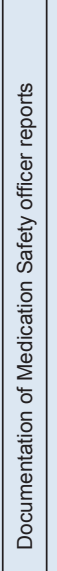 & 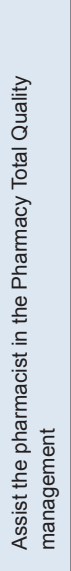 & 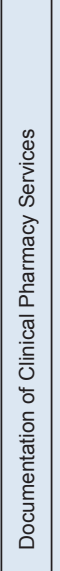 & 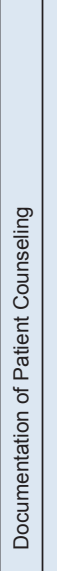 & 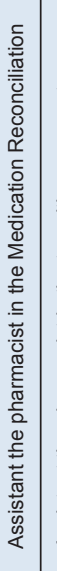 & 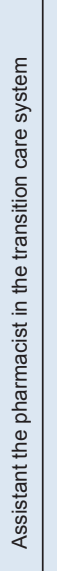 & 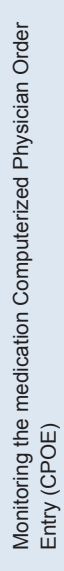 \\
\hline है & & & - & $\sim$ & $m$ & $\sigma$ & $\infty$ & 0 & $\wedge$ & $\infty$ & $\theta$ & $\div$ & $F$ & $\simeq$ & $\stackrel{m}{=}$ & \pm & $\stackrel{\circ}{\circ}$ & $\because$ & 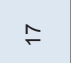 & $\stackrel{\infty}{\stackrel{\infty}{2}}$ & $\stackrel{\circ}{\circ}$ & จ & $\bar{N}$ & N \\
\hline
\end{tabular}




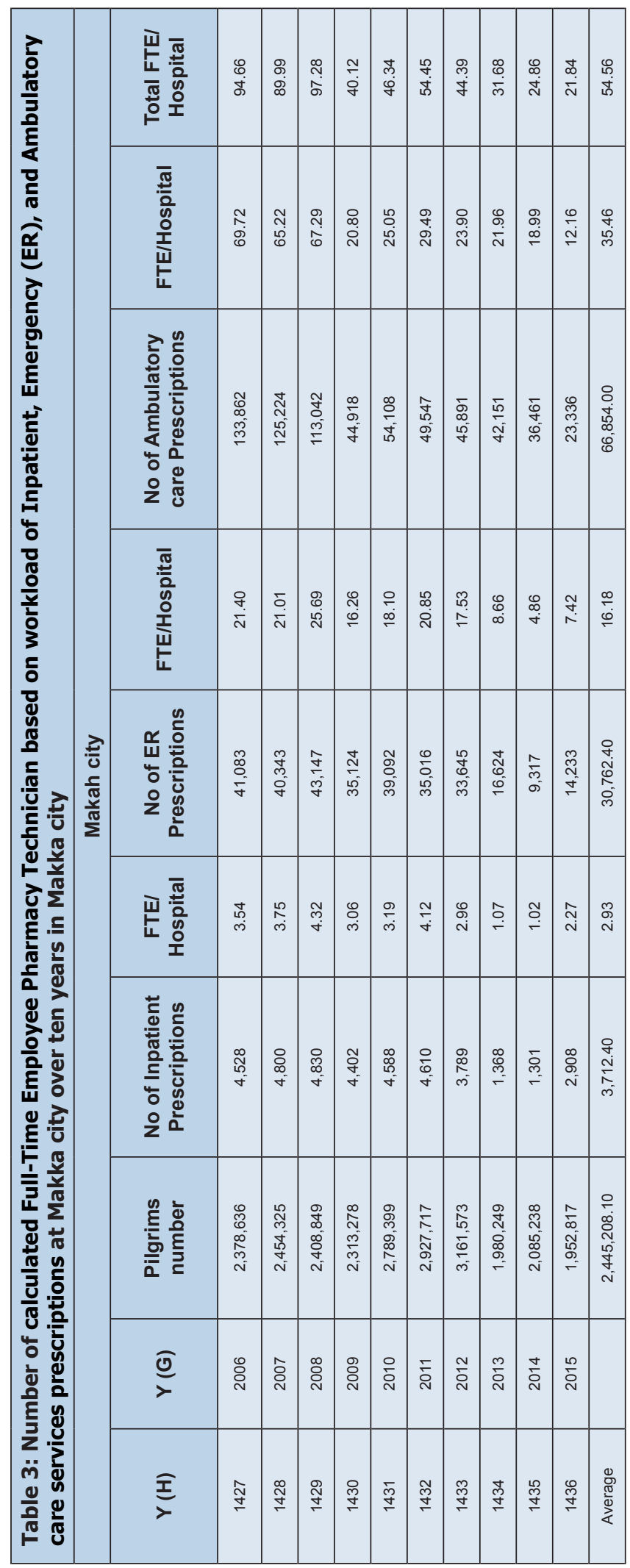

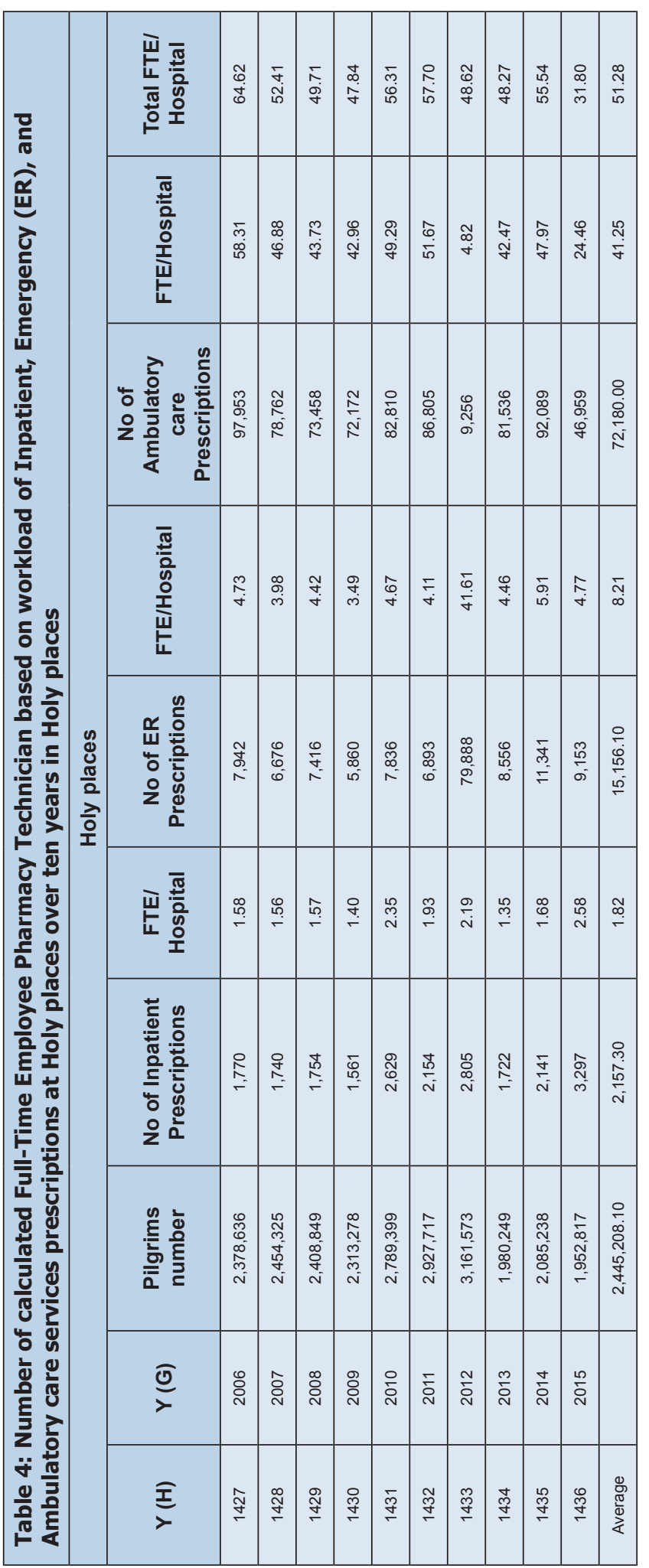


Pharmacy technician workforces at Hospitals during Hajj in Makka

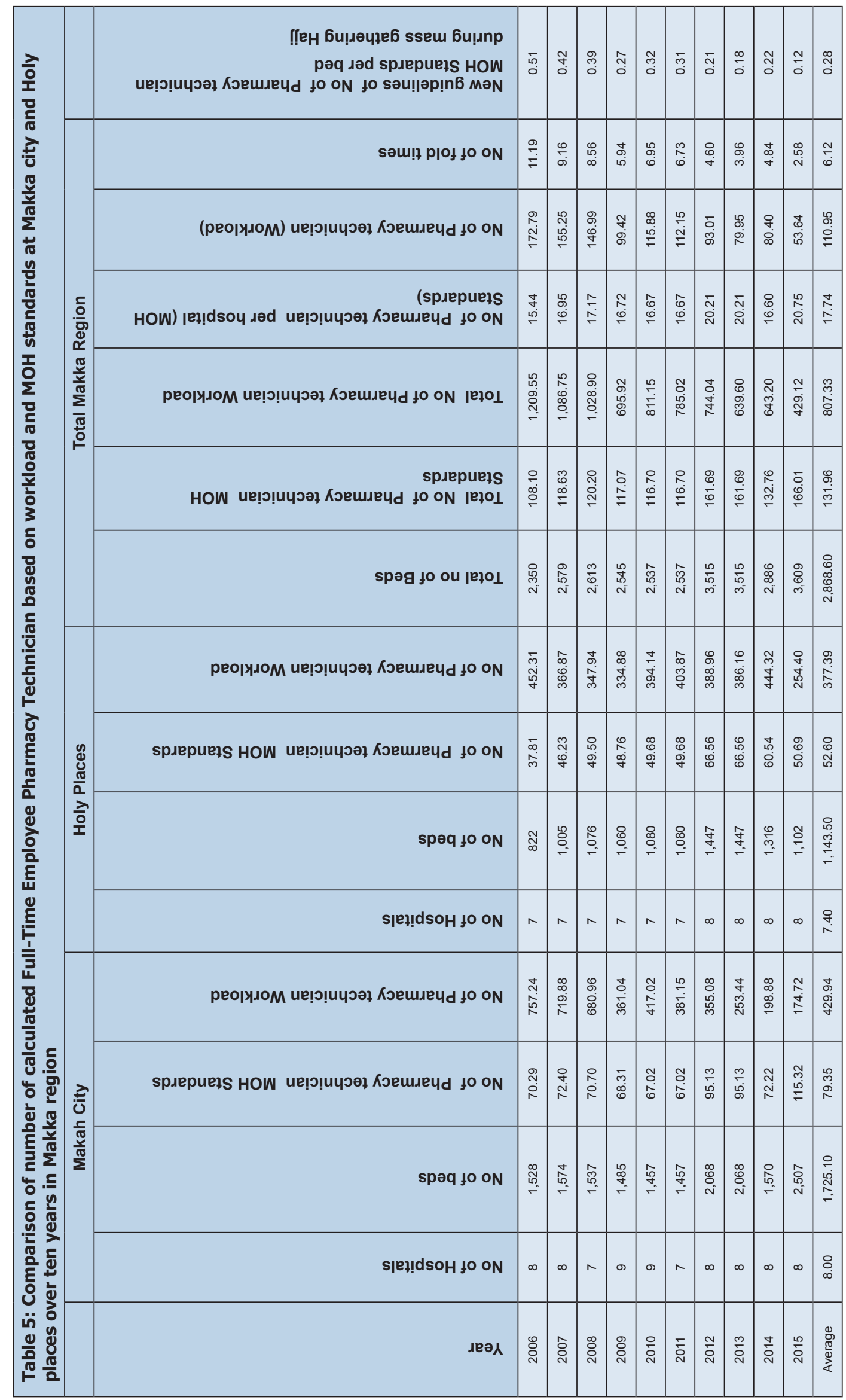


of five general strategic goals with initiatives and more than eighty projects. The pharmacy administration formulated several task forces committees to for project management and implementation. The pharmacy technician participated in several committees including public education committee, an electronic pharmacy automation committee. The public educational committee was one of the best and very active committees. The members participate in medication public education lectures, participated in writing on social media and organize them, published medication material at different languages for distribution during mass Gathering hajj period. The pharmacy administration implemented the ASHP guidelines of a pharmacy technician in pharmacy practice. ${ }^{[4]}$ The pharmacy technician prepares the medication for distribution through the pharmacist at all project of pharmacy practice. Also, the pharmacy technician participated at several short educational courses including Intravenous admixture, total parental nutrition. Also, it was starting point for pharmacy technicians advance performances in the clinical activities. Some pharmacy technician participated as co-authors with the publication of patient satisfaction of pharmacy services of primary care centers. ${ }^{[32]}$ All fundamental role of pharmacy technician implemented during mass gathering hajj time at hospitals and primary care centers when they started mass gathering medicine and mass gathering pharmaceutical care. The program consisted of mass gathering pharmacy practice, mass gathering clinical pharmacy, and mass gathering pharmacy workforces that have included the pharmacy technician. ${ }^{[33-34]}$ The author tried to investigate the pharmacy technician workforces during mass gathering important event called the Hajj over past ten years. The authors found very high demand based on workload calculation with pharmacy technician as compared to $\mathrm{MOH}$ standards. After very extensive literature review an only small number of studies discussed utilized physician and nurses during mass gathering events but not pharmacy technician. ${ }^{[35-37]}$ The authors cannot compare with other studies because this is the first study existed in the world for pharmacy technician workforces and workload calculation and requirements during mass gathering Hajj event. The author suggested the new guidelines with 0.28 pharmacy technician per bed during mass gathering Haji period. Also, another suggestion to solve the demand of the pharmacy technician by implementation the new system called Saudi managed care pharmacy the new initiative project recently published. ${ }^{[38-39]}$ The author did not calculate the workforce of pharmacist or clinical pharmacist it a further study in the future.

Limitation: There are several limitations with the study and it some time out of authors control. It included as follows; there is insufficient official data about pharmacy technician during mass gathering Hajj time over entire the study, it seems the first investigations in the world, there is no official documentation of pharmacy technician workload analysis during mass gathering Hajj time.

\section{CONCLUSION}

There is a high demand for pharmacy technicians during mass gathering Hajj time over past several years. The $\mathrm{MOH}$ standards of pharmacy technician should update during mass gathering event. All pharmacy activities including pharmacy technician performances should document during Haji period to refresh the calculation based on workload analysis during mass gathering Hajj period in the future studies in Makka region, Saudi Arabia

\section{ACKNOWLEDGEMENT}

I want to thank all staff at Health affairs administration and pharmaceutical care administration in Makkah region for their cooperation.

\section{CONFLICT OF INTEREST}

None

\section{ABBREVIATION USED}

KSA: Kingdom of Saudi Arabia, MOH: Ministry of Health, USA: United States of America, ACCP: American Collge of Clinical Pharmacy

\section{REFERENCES}

1. World Health Organization. Public health for mass gathering: key considerations. 2015; Available from www.who.int/about/licensing/ copyright_form/en/index.html

2. Saudi Ministry of Health. Health Statistical Year Book 2016. Available from: http://www.moh.gov.sa/en/ministry/statistics/book/pages/default.aspx

3. Ministry of Health. A Achievements 2013. 1st Ed. Riyadh, Saudi Arabia: Ministry of Health, Saudi Arabia; 2011. 132-135 p. Available from: http:// sgsminsk.by/_media/Global/Documents/Technical Documents/Technical Datasheets/SGS-PCA-SA-Datasheet SFDA-A4-EN-11-V2.pdf

4. ASHP. Roles and Responsibilities of Pharmacy Technicians. Am J Heal Pharm. 2016;73:928-30.

5. The Society of Hospital Pharmacists of Australia. Exploring the role of hospital pharmacy technicians and assistants to enhance the delivery of patient centered care A White Paper on the findings and outcomes of the, 2016. Available from: http://shpa.org.au

6. National Association of Pharmacy Regulatory Authorities. Professional Competencies for Canadian Pharmacists at Entry to Practice. 2007. Available from: http://napra.ca/content_files/files/comp_for_cdn_ pharmacists_at_entrytopractice_march2014_b.pdf

7. Mabasa VH, Malyuk DL, Tung A, Balen RM, Nicolls TR, Rahiman NL. Using Clinical Pharmacy Support Technicians to Optimize Pharmaceutical Care in the Intensive Care Unit. Can J Hosp Pharm. 2010; 63(1): 41-45. 
8. Mkeresztes J. Role of Pharmacy Technicians in the Development of Clinical Pharmacy. Ann Pharmacother. 2006;40:2015-9.

9. Alomi YA. Primary Care Center Pharmacy Manpower New Guidelines in Saudi Arabia. J Pharmacol Clin Res. 2016;1(1).

10. Saudi Ministry of Health. Health Statistical Year Book 2006. Available from http://www.moh.gov.sa/en/Ministry/Statistics/book/flash/1427/ $\mathrm{MOH}$ _Report_1427.html

11. Saudi Ministry of Health. Health Statistical Year Book 2007. Available from http://www.moh.gov.sa/en/Ministry/Statistics/book/flash/1428/ MOH_Report_1428.html

12. Saudi Ministry of Health. Health Statistical Year Book 2008. Available from: http://www.moh.gov.sa/en/Ministry/Statistics/book/flash/1429/ MOH_Report_1429.html

13. Saudi Ministry of Health. Health Statistical Year Book 2009. Available from http://www.moh.gov.sa/en/Ministry/Statistics/book/flash/1430/ MOH_Report_1430.html

14. Saudi Ministry of Health. Health Statistical Year Book 2010. 2010; Available from http://www.moh.gov.sa/en/Ministry/Statistics/book/Pages/default.aspx

15. Saudi Ministry of Health. Health Statistical Year Book 2011. Available from http://www.moh.gov.sa/en/Ministry/Statistics/book/Pages/default.aspx

16. Health Statistical Year Book 2012. Saudi Ministry of Health. Available from: http://www.moh.gov.sa/Ministry/Statistics/book/Documents/1433.pdf

17. Saudi Ministry of Health. Health Statistical Year Book 2013. Available from: http://www.moh.gov.sa/en/Ministry/Statistics/book/Pages/default.aspx

18. Saudi Ministry of Health. Health Statistical Year Book 2014. Available from: http://www.moh.gov.sa/en/Ministry/Statistics/book/Documents/StatisticalBook-for-the-Year-1435.pdf

19. Saudi Ministry of Health. Health Statistical Year Book 2015. Saudi Ministry of Health. Available from: http://www.moh.gov.sa/ministry/statistics/book/ pages/default.aspx

20. General Directorate of Health Affairs in Makah. Hospitals in Makah. Available from: http://mrhb.gov.sa/hospitals/reg/025

21. Ministry of Health. Al-Nour Specialist Hospital in Makkah Shows Continuous Readiness for the Hajj Season. Available from: http://www.moh.gov.sa/en/ Ministry/MediaCenter/News/Pages/News-2014-09-28-003.aspx

22. Ministry of Health. Ibn Sina Hospital Provides Supportive Medical Services to Pilgrims. Available from: http://www.moh.gov.sa/en/Ministry/MediaCenter/ News/Pages/news-2015-09-18-004.aspx

23. Ministry of Health. Ministry News - King Faisal Hospital in Makkah Completes its Preparations for the Pilgrims' Health Care. Available from: http://www.
moh.gov.sa/en/Ministry/MediaCenter/News/Pages/News-2012-10-21-003. aspx

24. SA International. King Abdullah Medical City: Mecca, Saudi Arabia. Available from: http://www.sainternational.us/Hospitals/agentType/View/PropertyID/1

25. General Directorate of Health Affairs in Makah. Hospitals in Holy Places. Available from: http://mrhb.gov.sa/hospitals/reg/099

26. Saudi Ministry of Health. Jabal AI Rahmah Hospital Gets Ready to Receive the Hajj Performers on Arafat Day. Available from: http://www.moh.gov.sa/ en/hajj/news/pages/news-2013-10-13-013.aspx

27. Alomi Y. A new Guidelines on Hospital Pharmacy Manpower in Saudi Arabia. J Pharm Pract Community Med. 2016;2(22):30-1.

28. Bond CA, Raehl CL, Franke T. Clinical pharmacy services and hospital mortality rates. Pharmacotherapy. 1999;19(5):556-64.

29. Bond C, Raehl C, Franke T. Total Cost of Care, and Length of Stay in United States Pharmacy Services and Staffing. Pharmacotherapy. 2001;21(2):129-41.

30. Bond CA, Raehl CL. Clinical pharmacy services, pharmacy staffing, and hospital mortality rates. Pharmacotherapy. 2007;27(4):481-93.

31. Alomi YA, Alghamdi SJ, Alattyh RA. Strategic Plan of General Administration of Pharmaceutical Care at Ministry of Health in Saudi Arabia 2012-2022. J Pharm Pharm Sci. 2015;1(3):1-8.

32. Alomi YA, Kurdy L, Aljarad Z, Basudan H, Almekwar B, Almahmood S. Patient satisfaction of pharmaceutical care of primary care centers at Ministry of Health in Saudi Arabia. J Pharm Pract Community Med. 2016;2(3):79-87.

33. Al-Tawfiq JA, Memish ZA. Mass gathering medicine: 2014 Hajj and Umra preparation as a leading example. Int J Infect Dis. 2014;27:26-31.

34. Alomi Y. National Mass Gathering Pharmaceutical Care Program at $\mathrm{MOH}$ in Saudi Arabia. J Pharm Pract Community Med. 2016;2(23):102-3.

35. Sanders Ab, Criss E, Stecki P, Meislin HWH, Raife J, Allen, et al. An analysis of medical care at mass gatherings. Ann Emerg Med. 1986;15(5):515-9.

36. Smith WP, Wessels V, Naicker D, Leuenberger E, Fuhri P, Wallis LA, et al. Development of a mass-gathering medical resource matrix for a developing world scenario. Prehosp Disaster Med. 2010;25(6):547-52.

37. Kollek D. An Introduction to Mass Gatherings. 2014; 1-16. Available from: http://www.ceep.ca/publications/Mass_Gatherings.pdf

38. Alomi YA. New Pharmacy Model for Vision 2030 in Saudi Arabia. J Pharm Pract Community Med. 2017;3(3).

39. Alomi YA, Alghamdi SJ, Alattyh RA. Saudi Managed Care Pharmacy (SMCP): New Initiative System of MOH Prescriptions Dispensed Through Community Pharmacies. J Pharm Pract Community Med. 2017;3(3):145-53.

Cite this article as: Alomi YA, Alhennawi K, Khayayt N. Pharmacy technician workload and workforce requirements at $\mathrm{MOH}$ Hospitals During ten years mass gathering Hajj (2006-2015) in Makah Region, Saudi Arabia. J Pharm Pract Community Med. 2017;3(4s):S107-S114. 